\title{
Implementation of Carbon Dioxide Gas Injection Method for Gas Recovery at Rashidpur Gas Field, Bangladesh
}

\author{
${ }^{1}$ Fatema Khatun, ${ }^{2}$ Md. Minhaj Uddin Monir, ${ }^{3}$ S.M. Nafefun Arham, ${ }^{4}$ Zularisam Ab Wahid \\ ${ }^{1,2}$ Department of Petroleum \& Mining Engineering, Jessore University of Science \& Technology, Bangladesh \\ ${ }^{3}$ Bangladesh Petroleum Exploration \& Production Company Ltd (BAPEX), Bangladesh \\ ${ }^{2,4}$ Faculty of Engineering Technology, University Malaysia Pahang, 26300, Kuantan, Pahang, Malaysia. \\ ${ }^{1}$ lubna.pme71@gmail.com, ${ }^{2}$ monir_pme@yahoo.com, ${ }^{3}$ nafefun@gmail.com, ${ }^{4}$ zularisam@ump.edu.my
}

\begin{abstract}
Natural gas plays an important role for the economic development of Bangladesh. It is the primary options to satisfy the environmentally clean energy, whereas coal is a dirty energy source and oil creates an unhealthy environment. Bangladesh is the seventh-largest producer of natural gas in Asia. Gas supplies meet $56 \%$ of domestic energy demand. The proven natural gas reserve in Bangladesh is only 19.73 Tcf. The Rashidpur Gas Field (RGF) is located in the Sylhet Basin, Northeast Bangladesh. It is 35 km long and $7 \mathrm{~km}$ anticlinal structure and asymmetric in nature with steeper eastern flank $\left(22^{\circ}\right.$ to $\left.25^{\circ}\right)$ and gentler western flank $\left(8^{\circ}\right.$ to $\left.12^{\circ}\right)$. There are two gas zones in depth between $1380 \mathrm{~m}$ to $2787 \mathrm{~m}$ below surface. Sandstone reservoirs of Miocene-Pliocene age and are considered to have been originated shallow marine depositional environment. The reservoir porosity-permeability values are very good, with estimated gas initially in place (GIIP) of the RGF was 2.242 Tcf with $58 \%$ recovery, thus recording an initial gas reserve is 1.309 Tcf. Five gas producing wells (RP-1, 3, 4, 6 and 7) in the RGF are producing 50 MMscf gas per day. Due to the demand of natural gas with decreasing production rate, this enhanced natural gas plays a vital role in the national economy of the country. This research depicts the development of the daily production of the RGF from 50 MMscfd to 99 MMscfd using software from the existing production wells. Thus the natural gas in the $\mathrm{RGF}$ would be enhanced/recovered using carbon dioxide $\left(\mathrm{CO}_{2}\right)$ gas injection by Enhanced Gas Recovery (EGR) method from the RGF reservoir. Applying this method would play a vital role to increase the daily production rate of the $R G F$.
\end{abstract}

Index Terms- Rashidpur gas field, enhanced gas recovery, carbon dioxide gas injection, trillion cubic feet.

\section{INTRODUCTION}

The Rashidpur gas field (RGF) is situated in the south central part of the Sylhet trough under Bahubal Upazila of Habiganj District (Figure 1). The area is located in between the latitudes $24^{\circ} 32^{\prime \prime} \mathrm{N}$ to $24^{\circ}$ $18^{\prime \prime} \mathrm{N}$ and the longitudes $91^{\circ} 30^{\prime \prime} \mathrm{E}$ to $91^{\circ} 43^{\prime \prime} \mathrm{E}$ [1]. The Sylhet Basin, known as the Surma Basin, is a sub Basin of the Bengal Basin, which is in the north eastern part of Bangladesh about 84 miles north east of Dhaka and 44 miles south east from Sylhet. Stratigraphically, the Tertiary Sylhet succession is subdivided into Jaintia, Barial, Surma, Tipam and Dupitila groups in ascending order (Table 1). Bangladesh is the one of the largest gas producer in Asia, and now it has proven to be only $19.73 \mathrm{Tcf}$ natural gas reserves [2]. A total of 26 gas fields were discovered in Bangladesh and some more fields yet to be declared [3]. This existing reserve $16.74 \mathrm{Tcf}$ is set to be exhausted within next one decade, and the gas production rate will be decreased steadily from 2017 [4]. Currently the country produces daily 2500 MMscf gas per day from 19 producing gas fields, and it is not sufficient, as its major source of primary energy used as gas [2]. If this continues, it is assume that, Bangladesh will face a major setback in industrialization, and against the demand for gas 2700-3000 Bcf per day instead of $2.28 \mathrm{Bcf}$ makes the country one day to be dry up. Coal has been used since the industrial revolution and became the major source of energy [5]. And by the middle of the twentieth century oil indeed dominated the economics and politics of the world. As the contribution of the greenhouse gases to the atmosphere by burning coal and oil became more alarming, natural gas was preferred as cleaner and environmentally friendly. Natural gas contains virtually no sulphur or sulphur compounds, coal and oil accounted for approximately $99 \%$ of fossil fuel emissions of sulphur dioxide which is harmful for the environment [6]. In Bangladesh, sectored use of natural gas during year 2003-04, is power generation plants use about $51 \%$, fertilizer industry $21 \%$ and remaining $30 \%$ gas used in industrial, 
commercial and domestic sector with system loss 5\% [6]. From the year of 2004 to 2013 the daily production of natural gas is reduced as 1305 MMscfd (million cubic feet per day) to $1063 \mathrm{MMscfd}$ [6]. It is needed to enhance the rest of the gas, based on initial evaluation of field reserve as the reservoir characteristics of Bangladesh are moderate to high porosity and permeability [5]. Maximum gas recovered from the reservoir is done by primary recovery (20-30\%), secondary recovery $(40 \%)$. Using modern recovery technique or improved technique or tertiary technique known as Enhanced Oil Recovery (EOR) recovered 60-65\% [7]. Enhanced Gas Recovery (EGR) can be achieved using $\mathrm{CO}_{2}$ as it is heavier than natural gas [8]. $\mathrm{CO}_{2}$ gas injection methods include two main groups of miscible and immiscible gas injection. In the immiscible method gas is not miscible with the reservoir fluid on the other hand the miscibility mechanism is to solvent extraction to achieve miscibility [9].

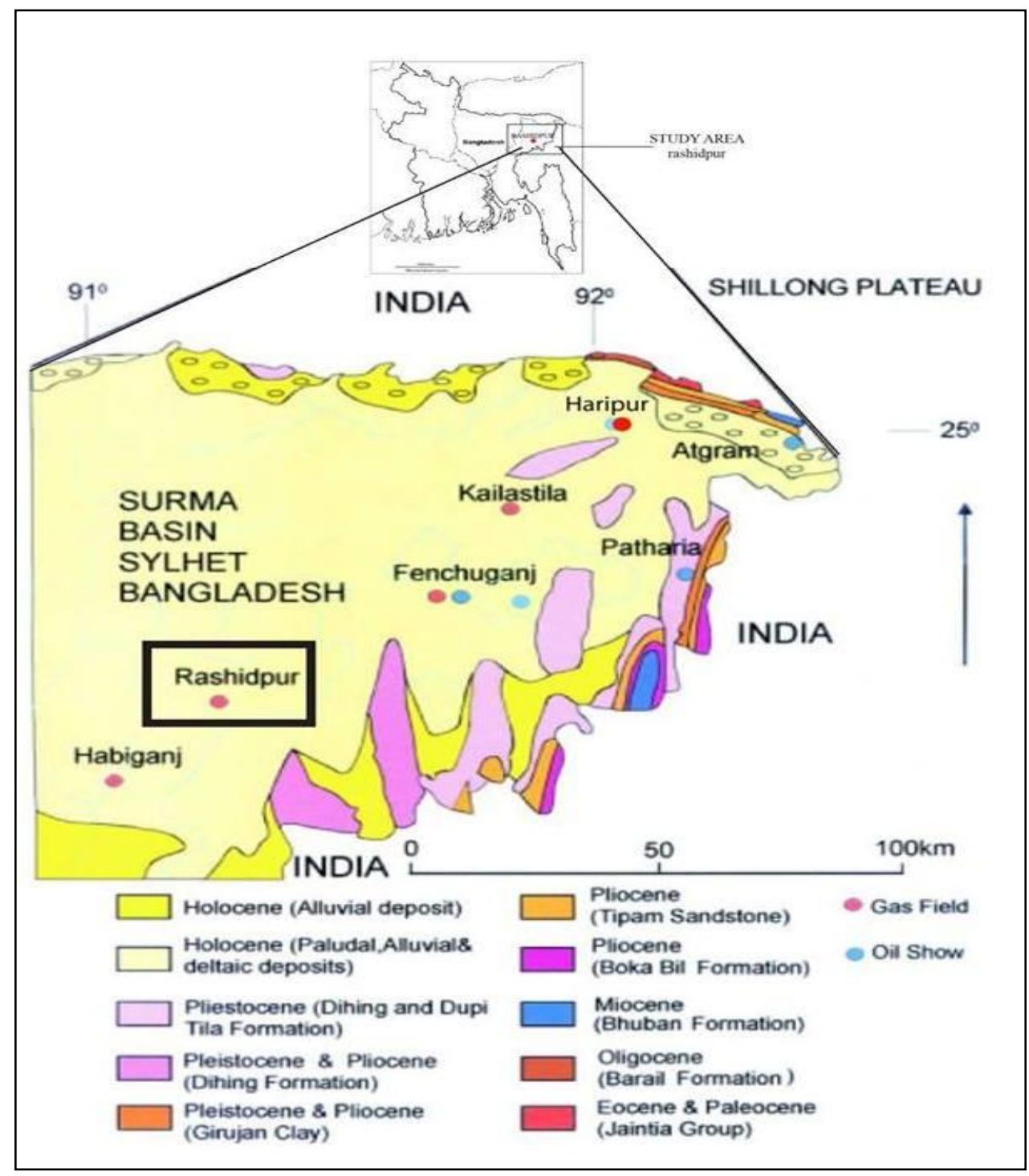

Figure 1 Location Map of the Study Area, (Surma Basin, Sylhet, Bangladesh) (Modified after [10])

Bengal Basin is a fruitful hydrocarbon-bearing basin in Southeast Asia. The Sylhet Basin known as the Surma Basin is a sub-basin of the Bengal Basin. The Surma Basin is of great importance in cause of sediment thickness probably exceeds $20 \mathrm{~km}$ and economic deposits [11]. The Rashidpur structure is an anticlinal structure situated in the southern part of the Surma Basin [12]. The anticline is northsouth trending, $35 \mathrm{~km}$ long, $7 \mathrm{~km}$ wide, and is asymmetric in nature with steeper $\left(22^{\circ}\right.$ to $\left.25^{\circ}\right)$ eastern flank and gentler $\left(8^{\circ}\right.$ to $\left.12^{\circ}\right)$ western flank [12]. The Rashidpur field is geologically complex and the 
gas is distributed in at least five stacked sand bodies. Upper Gas Sand 1(UGS1), Upper Gas Sand 2(UGS2), Middle Gas Sand 1(MGS1), Middle Gas Sand 2(MGS2), and Lower Gas Sand (LGS) in increasing order of depth [13]. RGF has two producing zones named as Upper Gas Sand (UGS) and Lower Gas Sand (LGS), estimated reserve 0.54 Tcf and 1.26 Tcf respectively [14].

The RGF has a capacity of 200 MMscfd gas, with Gas initially in place (GIIP) was 2.242 Tcf [13]. Current production rate of RGF is $47 \mathrm{MMscfd}$ and condensate reserve is 55.3 BBL [2]. There are seven wells at RGF; among them five wells (RP-1, 3, 4, 6 and 7) are producing wells. The RGF well known as (RP) 1, 2, 3, 5, 6, and 7 are vertical well and RP-4 is deviated well. Currently gas production rate of individual wells are $19 \mathrm{MMscfd}$, 11MMscfd, 12MMscfd, 1MMscfd and $8 \mathrm{MMscfd}$ from RP 1, 3, 4, 6 and 7 well [13]. The aims of this study is to enhance the natural gas production rate in the RGF by applying one of the most renowned enhancing method, by injecting carbon dioxide $\left(\mathrm{CO}_{2)}\right.$ gas.

\section{GEOLOGICAL SETTING}

The Bengal Basin is placed in the easternmost part of the Indian sub-continent occupying whole Bangladesh and part of India and Myanmar. Bengal basin is bounded by the Indian Shield Platform to the west, north by the Precambrian Shillong Massif, to the east by the Indo-Burman ranges and plunges in to the Bay of Bengal to the south, and the Surma Basin is located in the northeastern part of the Bengal Basin [15], [16]. The lowermost unit, the Jaintia Group is subdivided into the Tura Sandstone, Sylhet Limestone and Kopili Shale Formations, in ascending order. The Tura Sandstone Formation consists mainly of poorly sorted sandstones, mudstones, some carbonaceous material and impure limestones, and was deposited in shallow to deep marine environments [17]. The Barail group (late Eocene to early Miocene) consists mainly of clastic sediments and is divided into the basal Jenam Formation (predominantly shale) and the overlying Renji Formation (mainly sandstone, with interbedded siltstone and a shale) [18]. The overlying Surma Group (middle to late Miocene) consists of alternating sandstones, siltstones and mudstones and is lithologically divided into the mostly arenaceousBhuban Formation and the dominantly Bokabil Formation. The RGF is an asymmetric anticline with north-south trending axis and located south central part of the Surma Basin (Figure 2). The anticlinal structure is about $35 \mathrm{~km}$ long and $7 \mathrm{~km}$ wide. Stratigraphic succession of the Sylhet Basin is shown in Table 1.

Table 1 Stratigraphy of the Sylhet Basin, Bangladesh (after [16])

\begin{tabular}{|c|c|c|c|c|}
\hline Age & Group & Formation & Lithology & $\begin{array}{l}\text { Depositional } \\
\text { Environment }\end{array}$ \\
\hline Recent & Alluvium & Alluvium & Sand, Silt, Clay & Fluvial \\
\hline Late Pleistocene & Dihing & Dihing & Sandstone, Shale & Fluvial \\
\hline Pliocene-Pleistocene & Dupitila & Dupitila & Sandstone, Shale & Fluvial \\
\hline $\begin{array}{l}\text { Late Miocene- } \\
\text { Pliocene }\end{array}$ & Tipam & $\begin{array}{l}\text { Girujan Clay } \\
\text { Tipam } \\
\text { Sandstone }\end{array}$ & $\begin{array}{l}\text { Clay, Sandstone } \\
\text { Sandstone, Shale }\end{array}$ & $\begin{array}{c}\text { Fluvial, Lacustrine } \\
\text { Fluvial }\end{array}$ \\
\hline Middle-Late Miocene & Surma & $\begin{array}{l}\text { Bokabil } \\
\text { Bhuban }\end{array}$ & $\begin{array}{l}\text { Sandstone, Shale } \\
\text { Sandstone, Shale }\end{array}$ & Marine, Deltaic \\
\hline $\begin{array}{l}\text { Late Eocene-early } \\
\text { Miocene }\end{array}$ & Barail & $\begin{array}{l}\text { Renji } \\
\text { Jenam }\end{array}$ & $\begin{array}{l}\text { Sandstone, Shale } \\
\text { Shale, Sandstone }\end{array}$ & Shallow marine, deltaic \\
\hline $\begin{array}{l}\text { Late Eocene } \\
\text { Early-middle Eocene }\end{array}$ & Jaintia & $\begin{array}{l}\text { Kopili Shale } \\
\text { Sylhet } \\
\text { Limestone }\end{array}$ & $\begin{array}{l}\text { Shale, minor lst. } \\
\text { Limestone }\end{array}$ & $\begin{array}{c}\text { Shallow marine, deltaic } \\
\text { Shallow marine }\end{array}$ \\
\hline $\begin{array}{l}\text { Paleocene-early } \\
\text { Eocene }\end{array}$ & & Tura Sandstone & Quartz arenitese & Shallow marine \\
\hline
\end{tabular}




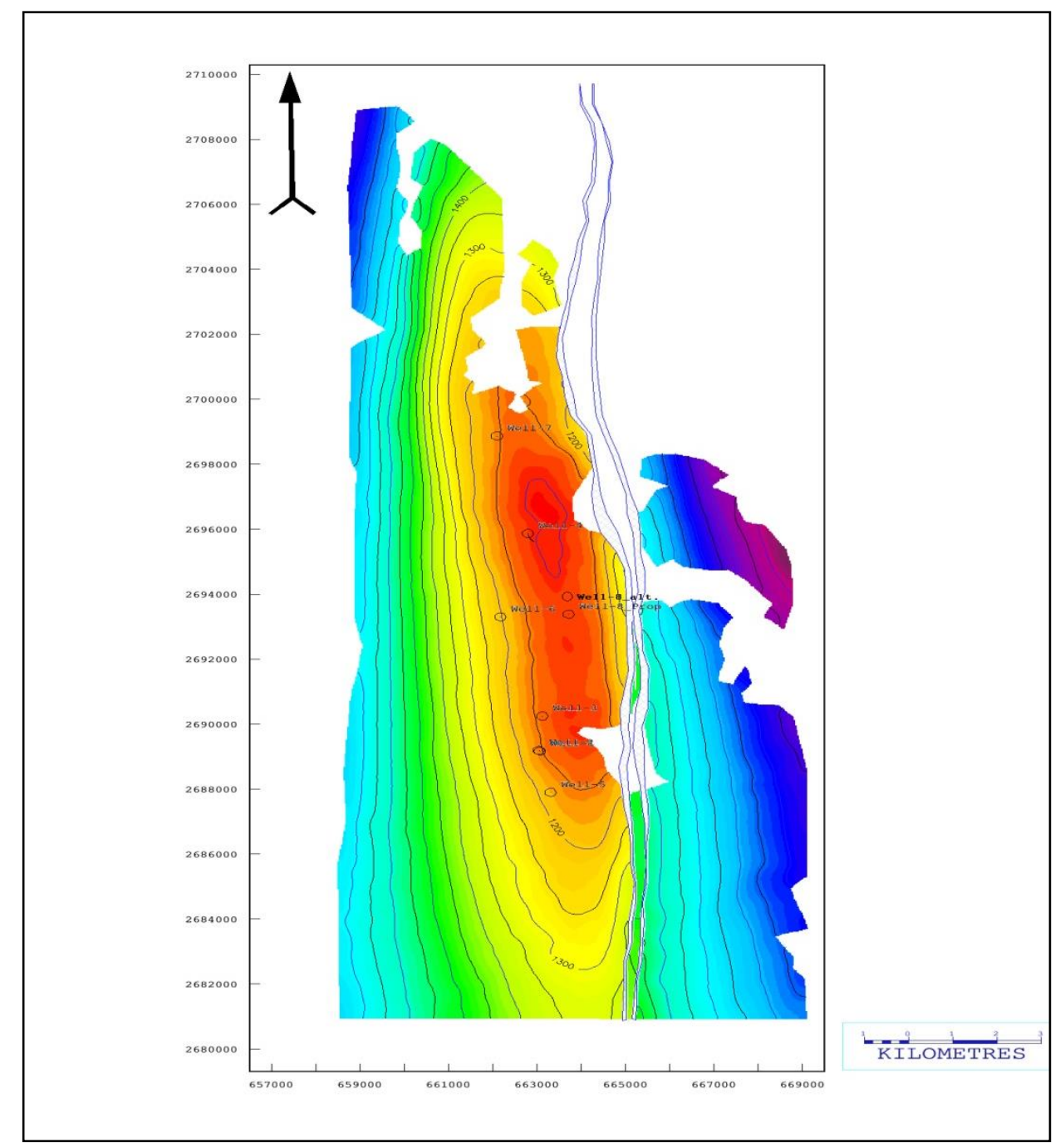

Figure 2 Drilling location of proposed well at RGF on the depth contour map of UMS sand

\section{MATERIALS AND METHODS}

The RGF has a daily facility capacity of natural gas is 220 MMscfd, but it produces only 50 MMscfd. When a reservoir pressure is decreased or depleted through primary and secondary production, carbon dioxide gas injection can be an ideal recovery method [19]. Combination of $\mathrm{CO}_{2} \mathrm{EGR}$ and storage in reservoirs provides a bridge between reducing greenhouse gases from industrial waste streams and the beneficial use of $\mathrm{CO}_{2}$ injection for increasing gas recovery. After injecting carbon dioxide gas through the well the results are calculated from MATLAB simulation software and the two curves, Inflow Performance Relationship (IPR) curve and Vertical Lift Performance (VLP) curve intersection point provides expected production rate or flow rate of the RGF.

A reservoir model is done by using GOOGLE SKETCH UP 8 and PHOTOSHOP CS 6 software. IPR and VLP curve is generated by using MATLAB software and to generate this curve a number of data is being entered into the software. To set up this curve it is entered into reservoir pressure data and flowing wellhead pressure (fwhp) data simultaneously. Carbon dioxide $\left(\mathrm{CO}_{2}\right)$ gas injection is a very famous enhanced recovery process, for choosing this method it is mentioned that the carbon dioxide gas has two special characteristics:

- Miscibility

- Less expensive than other similarly miscible fluids 


\section{RESULTS AND DISCUSSIONS}

The large quantities of natural gas in the RGF are existed in the gas bearing formations. Gas initially in place (GIIP) of the RGF was 2.242 Tcf with $58 \%$ recovery by IKM (1992), thus recording an initial gas reserve 1.309 Tcf. HCU/NPD re-estimated the GIIP at 2.202 Tcf with a suggested 70\% (1.401 Tcf) recovery, and remaining 30\% reserve is unrecoverable [20]. Five gas producing wells (RP- 1, 3, 4, 6 and 7) in the RGF are producing 50 MMscf gas per day [13]. Average daily gas production of the RGF was 92 MMscfd [21]. The daily production of the RGF is decreasing day by day and it creates a great loss of the fuels. In order to increase the daily production rate and also recover remain gas from the RGF; a renewable enhanced carbon dioxide gas injection method is to be applied. This EGR method can be applied for the RGF to enhance gas recovery used RP-7 and RP-5 as injecting wells for $\mathrm{CO}_{2}$ gas injection. As RP-5 well is the southernmost well, production declined over time and well got loaded with water. Both RP-7 and RP-5 well is situated at the periphery of the RGF, Injecting $\mathrm{CO}_{2}$ gas through these well could be recover the natural gas from all over the RGF reservoir, as it is an egg shaped reservoir. To enhance the daily production rate from the RGF gas reservoir a simultaneous work is done by MATLAB simulation software. Carbon dioxide gas injection EGR method is being used to enhance the daily gas production rate of the RGF. To calculate the gas production optimization of the RP-1, 3, 4 and 7, it is done by decreasing reservoir pressure with changing wellhead pressure.

\subsection{Reservoir model of the $R G F$}

There are seven wells at Rashidpur gas field, five wells (RP-1, 3, 4, 6, and 7) among them are gas producing wells. RP-1, 2, 3, 5, 6, 7 wells are vertical well; RP-4 is deviated well. The gas producing rate at RP-1, 3, 4, 6 and 7 wells during June, 2011 are 19 MMscfd, 11 MMscfd, 12 MMscfd, 1 MMscfd and 8 MMscfd respectively [13]. Gas recovery from the RGF with the two vertical well as RP-7 and RP-5 suggested as an injection well and a proposing model of the RGF using GOOGLE SKETCH UP 8 and PHOTOSHOP CS 6 software is shown in figure 3.

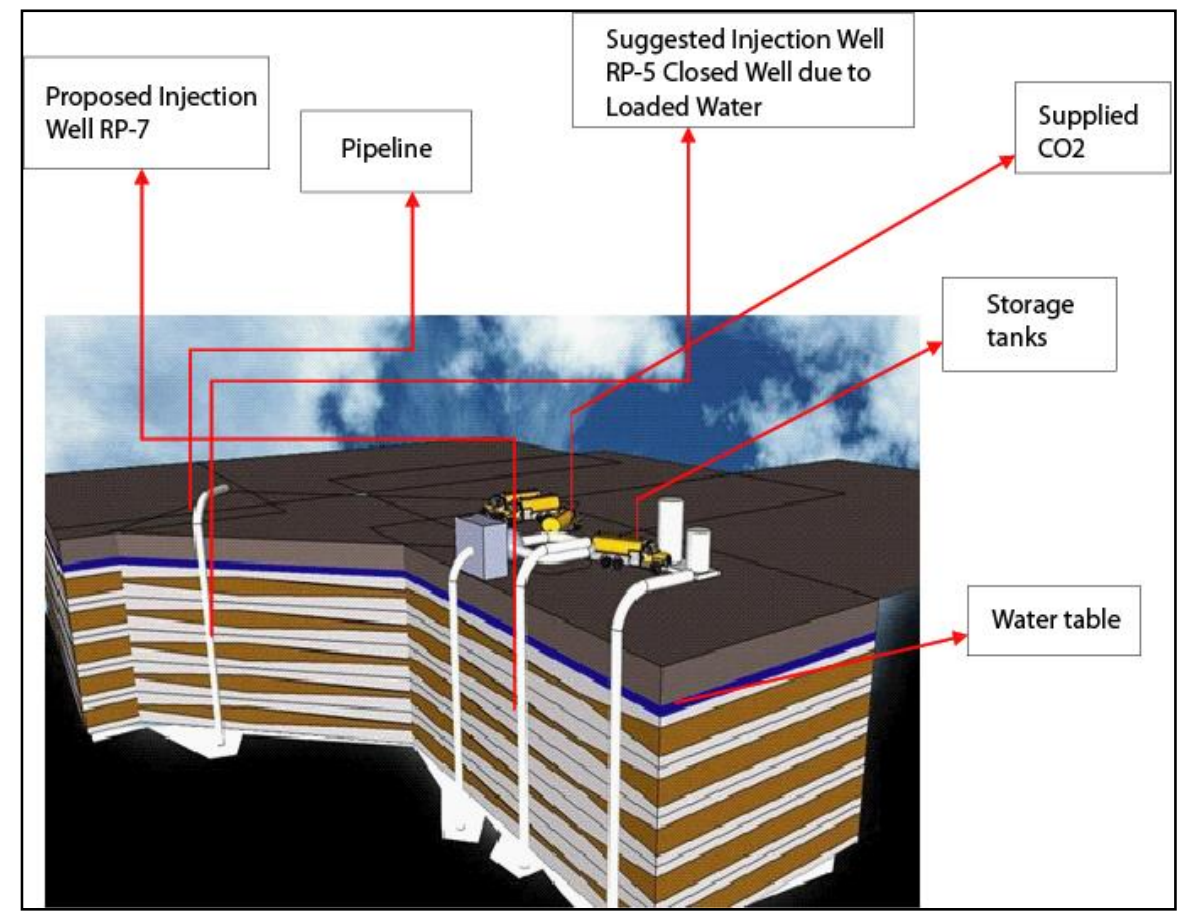




\section{Figure 3 Schematic diagram of the equipment layout in $\mathrm{CO}_{2}$ treatments at RGF}

\subsection{Increased efficiency/sufficiency of Gas - using miscible $\mathrm{CO}_{2}$ gas injection method}

Using carbon dioxide $\left(\mathrm{CO}_{2}\right)$ from nearby industrial waste into the RGF reservoirs EGR can be achieved as $\mathrm{CO}_{2}$ is heavier than natural gas. The main benefit of $\mathrm{CO}_{2}$ injection is pressure support to prevent subsidence and water intrusion. This injected $\mathrm{CO}_{2}$ enters the RGF reservoirs and moves through the pore space of the rock as it has very good porosity and permeability. After injecting $\mathrm{CO}_{2}$, the results are found from MATLAB software. The two curves, Inflow Performance Relationship (IPR) curve and Vertical List Performance (VLP) intersection point provides expected production rate or flow rate of the RGF. After injection of $\mathrm{CO}_{2}$ gas, due to pressure difference, the daily production of the RGF is found from the well RP-1, 3, 4, and 7.

\subsubsection{Well RP-1}

RP-1 well is one of the gas producing well of the RGF. It was drilled in 1960 to $9099 \mathrm{ft}$ (2774m) MD. It is a vertical well. RP-1 and reported to encounter gas in two sands in upper gas sand (UGS1) and lower gas sand (LGS). Currently daily producing range of natural gas is 18-20 MMscfd. After injection of $\mathrm{CO}_{2}$ gas into the RGF reservoirs, the production rate of RP-1 will be increased as 31 MMscfd.

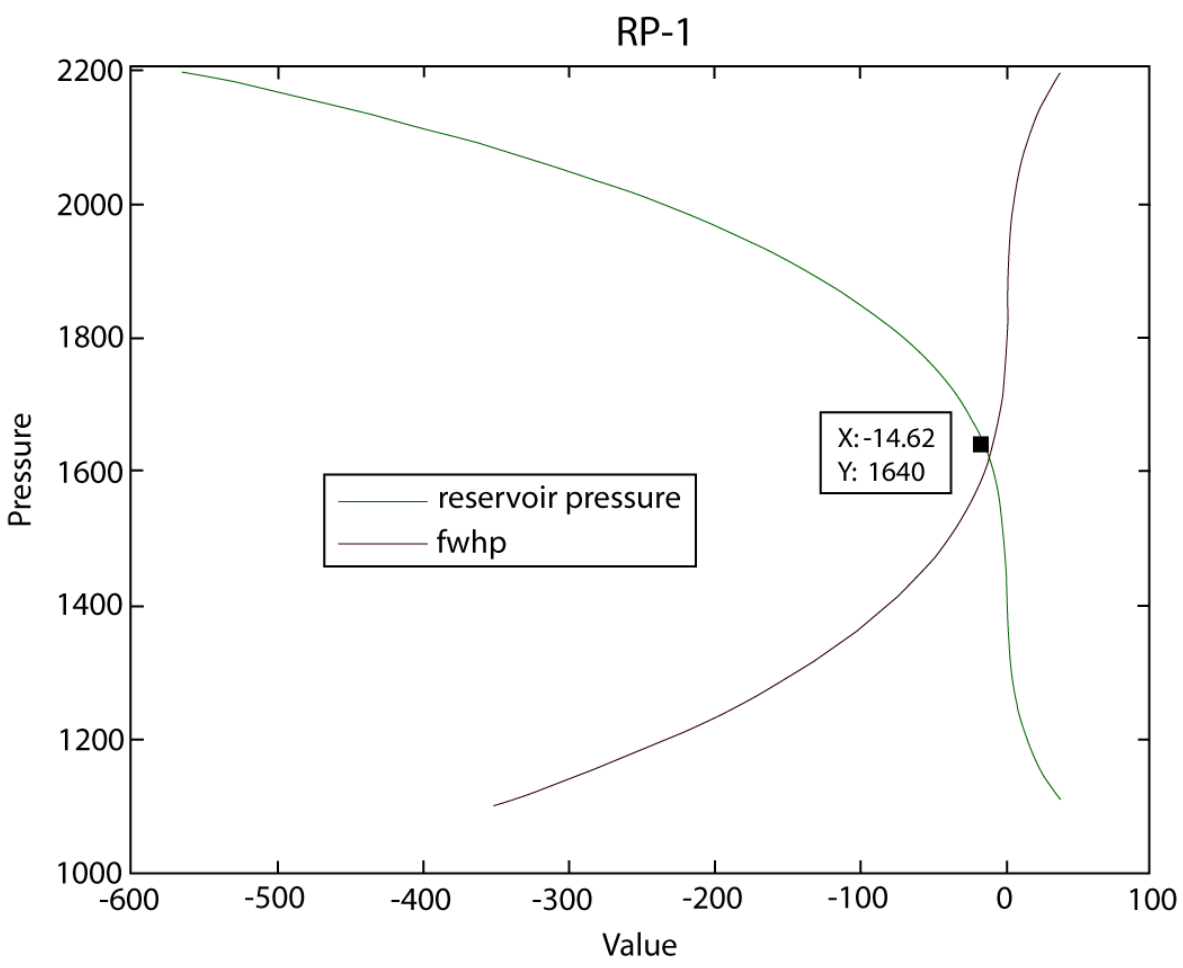

Figure 4 A graphical representation of IPR-VLP curve after applying $\mathrm{CO}_{2}$ gas injection method using MATLAB software at RP-1

\subsubsection{Well RP-3}

RP-3 was drilled in 1989 to $9711 \mathrm{ft}$ (2960m) MD as a vertical well. RP-3 is reported to encounter gas in upper gas sand 1(UGS1), upper gas sand 2(UGS2), lower gas sand (LGS). The well was completed in LGS. Currently daily producing range of natural gas is 10-11 MMscfd. After injection of $\mathrm{CO}_{2}$ gas into the RGF reservoir, the production rate of RP-3 will be increased as 23 MMscfd. 
RP-3

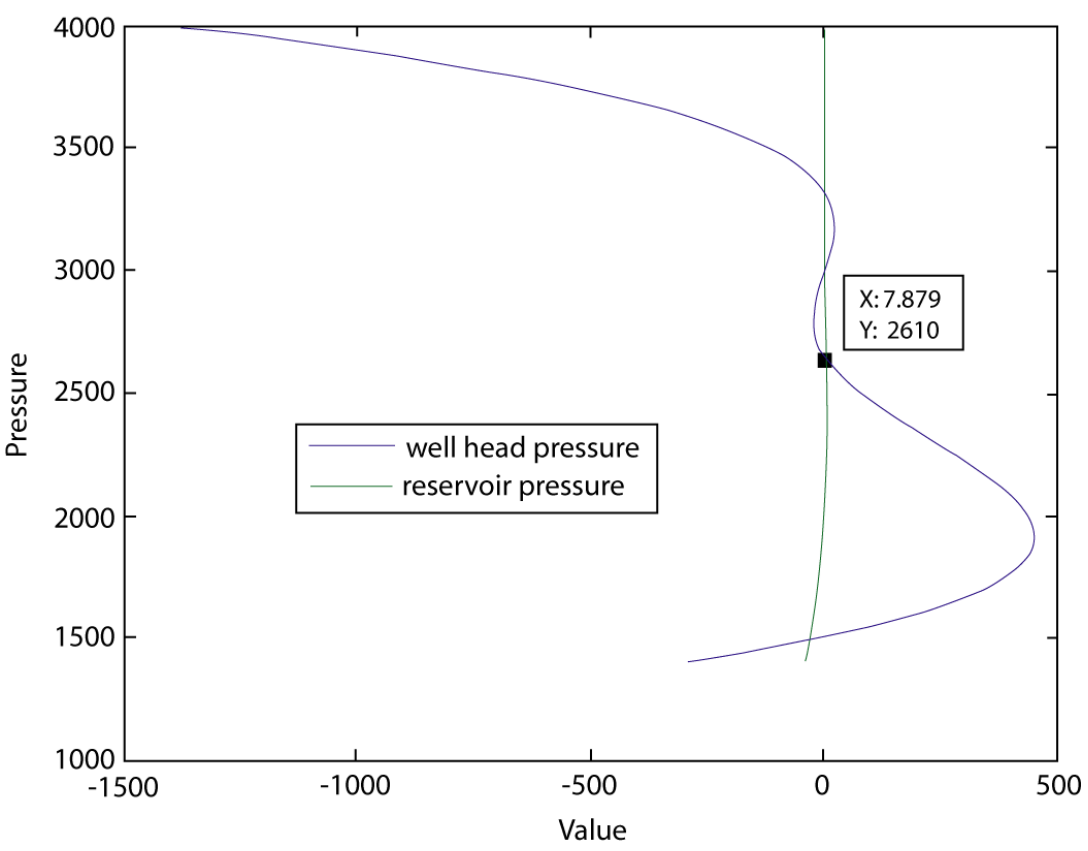

Figure 5 A graphical representation of IPR-VLP curve after applying $\mathrm{CO}_{2}$ gas injection method using MATLAB software at RP-3

4.2.3 Well RP-4

RP-4 was drilled in 1989 as a deviated well. RP-4 is reported to encounter gas in upper gas sand 2(UGS2), lower gas sand (LGS), LGS2. The well was completed in LGS2 sands. Average daily producing range of natural gas is $10-20 \mathrm{MMscfd}$. After injection of $\mathrm{CO}_{2}$ gas into the RGF reservoir, the production rate of RP-4 will be increased as 21 MMscfd.

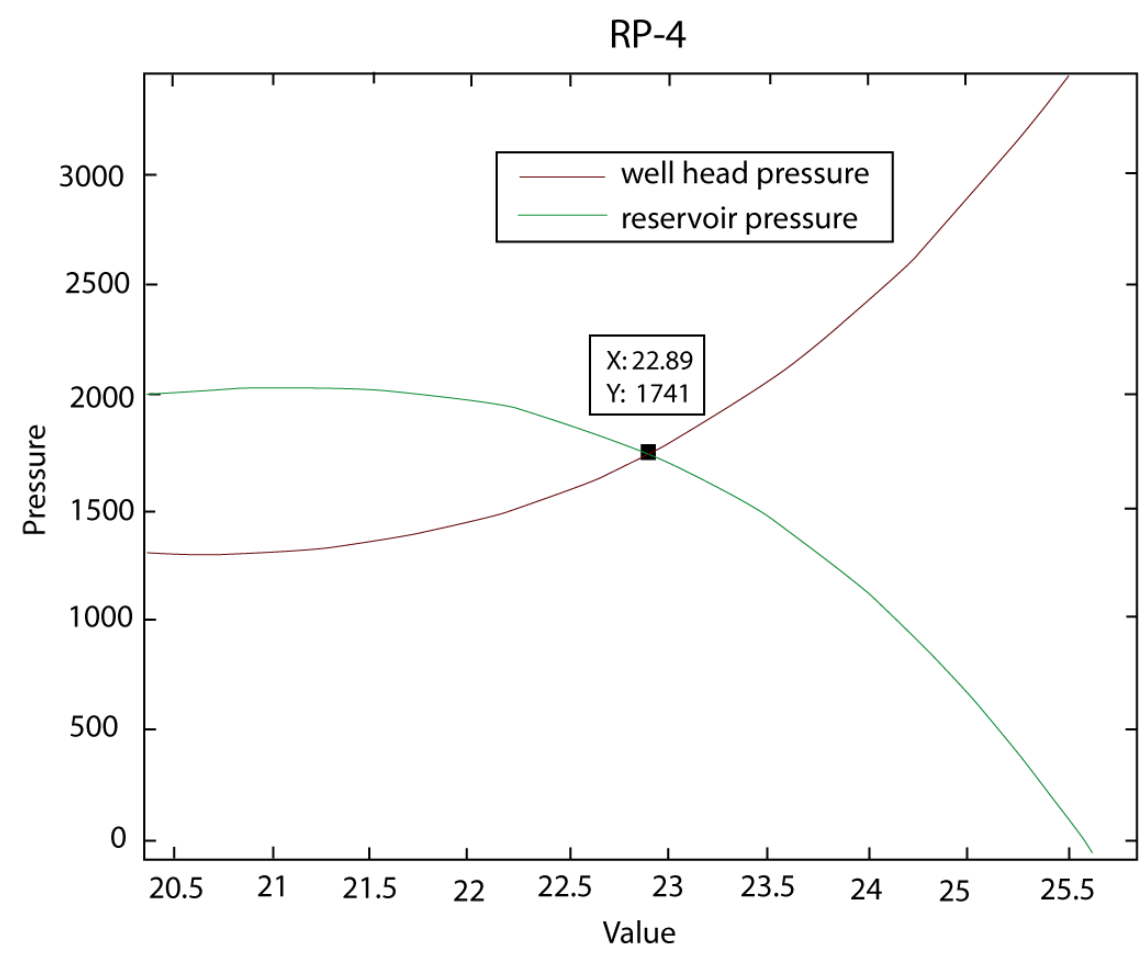

Figure 6 A graphical representation of IPR-VLP curve after applying $\mathrm{CO}_{2}$ gas injection method using MATLAB software at RP-4 


\subsubsection{Well RP-7}

RP-7 was drilled in 1999 to $2892 \mathrm{~m}$ MD as a vertical well. It has encountered gas in UGS1 and LGS1. Average daily producing range of natural gas is 7-8 MMscfd. After injection of $\mathrm{CO}_{2}$ gas into the RGF reservoir, the production rate of RP-7 will be increased as 24 MMscfd.

RP-7

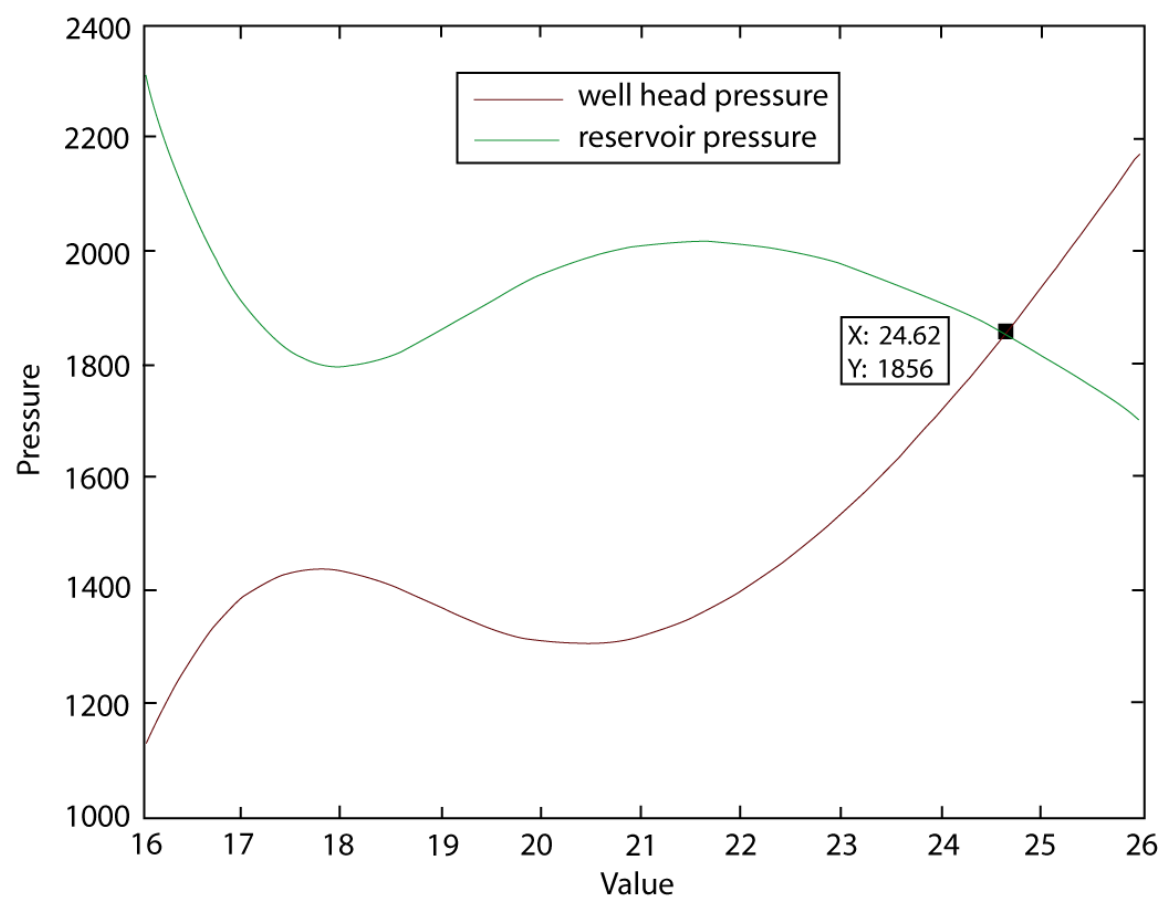

Figure 7 A graphical representation of IPR-VLP curve after applying $\mathrm{CO}_{2}$ gas injection method using MATLAB software at RP-7

A graphical representation of IPR-VLP curve after applying $\mathrm{CO}_{2}$ gas injection method using MATLAB software at RP-1, 3, 4, 7 are 31 MMscfd, 23 MMscfd, 21 MMscfd, 24 MMscfd respectively. After the simulation work it is indicate that if the RGF will apply $\mathrm{CO}_{2}$ EGR method, the daily production rate will increase to (31 MMscfd+23 MMscfd+21 MMscfd+24 MMscfd) 99 MMscfd instead of 50 MMscfd [13]. Using this EGR method the production rate of the RGF will be twice than the previous daily production rate. This excess production of natural gas from the RGF may fulfill the demand of energy in Bangladesh and the economy will go smoothly.

\section{CONCLUSIONS}

The recoverable reserve of the Rashidpur Gas Field (RGF) is 1481 BCF (3D seismic 2012), 2433 BCF (RPS Energy 2009), and 1401 BCF [20]. The cumulative production rate is $554.71 \mathrm{BCF}$. The RGF has a daily production capacity of the natural gas is $220 \mathrm{MMscfd}$, but it produces only 50 MMscfd. Five gas production wells of the RGF (RP 1, 3, 4, and 7) producing 50 MMscfd [12]. After implementing $\mathrm{CO}_{2}$ injection method using MATLAB simulation software at RP-1, 3, 4, and 7, the daily production rate will increase to $31 \mathrm{MMscfd}, 23 \mathrm{MMscfd}, 21 \mathrm{MMscfd}, 24 \mathrm{MMscfd}$ respectively. Ultimately the daily production rate of the RGF will be increased to $99 \mathrm{MMscfd}$, which is about twice than the previous production rate. For the fulfillment of present energy demand in Bangladesh the RGF will produce extra gas from the existing wells by the implementation of carbon dioxide enhanced gas recovery method. Therefore, this EGR method would be the right option in Bangladesh to extract additional gas from existing gas reservoir at RGF. 


\section{ACKNOWLEDGEMENT}

The authors would like to thanks to Ar. Md. Abdullah and Mustafizur Rahman for their cordial help and also thanks to Md. Shaheen Shah, Lecturer, department of Petroleum and Mining Engineering, Jessore University of Science and Technology for his cooperation.

\section{REFERENCES}

[1]. A.R.M.T Islam, M.A. Habib, M.T. Islam, \& M.R. Mita, "Interpretation of Wireline Log Data for Reservoir Characterization of the Rashidpur Gas Field, Bengal Basin, Bangladesh" IOSR Journal of Applied Geology and Geophysics (IOSR-JAGG), vol. 1 (4), pp.47-54, 2013.

[2]. Petrobangla, Annual Report of Bangladesh Oil, Gas and Mineral Corporation, www.petrobangla.org.bd, 2014.

[3]. B. Imam, Energy Resources of Bangladesh, Second Edition, 2013.

[4]. JICA, The study for Master plan on coal power development in the republic of Bangladesh, power system Master plan 2010, Final Report, prepared by Japan International Cooperation Agency (JICA), for People's Republic of Bangladesh, Ministry of power, Energy and Mineral resources, Government of Bangladesh, 2011.

[5]. B. Imam, Energy Resources of Bangladesh, 2005.

[6]. M.W. Burnett, S.D. Bann, Changing Projects for natural gas in the United States, vol. 204, pp. 305-309,1989.

[7]. Al-Sulaimani, H., Joshi, S., Al-Wahaibi, Y., Al-Bahry, S., Elshafie, A., \& Al-Bemani, A. "Microbial biotechnology for enhancing oil recovery: current developments and future prospects" Biotechnol. Bioinf. Bioeng, vol. 1(2), pp. 147-158, 2011.

[8]. S.Q Tunio, A.H Tunio, N.A. Ghirano \&ZMLE Adway, "Comparison of Different Enhanced Oil Recovery Techniques for Better Oil Productivity", International Journal of Applied Science and Technology, vol. 1 (5), pp. 143-153, 2011.

[9]. A. Kamari, A.H. Mohammadi, "Screening of Enhanced Oil Recovery Methods", ISBN: 9781-63321-856-7, Nova science Publishers, Inc, pp. 286-295, 2014.

[10]. M. Mannan, "Stratigraphical Evolution and Geochemistry of The Neogene Surma Group, Surma Basin, Sylhet, Bangladesh", Department of Geology, University of Oulu, 2002.

[11]. K.A. Islam, D. Hossain, "Interpretation of Seismic Data of the Kailas Tila Structure in the Surma Basin, Bangladesh", Journal of the Geological Society of India, Vol. 60, no. 3, pp. 271-281, 2002.

[12]. A. Reza, M.T. Islam, M.A. Habib, "Identification of Gas Sand Horizons of the Rashidpur Structure ,Surma Basin, Bangladesh, Using 2D Seismic Interpretation”, Inetrnational Journal of Geophysics, Article ID, 840168, pp. 1-10, 2015.

[13]. Schlumberger, Consultancy Services for Gas Production Augmentation Strengthening of the hydrocarbon Unit HCUCS/8(Phase-II), Bangladesh, 2011.

[14]. M.M. Huque, "Production Optimization of Rashidpur Gas Field, Bangladesh", Faculty of Science and Techbology, University of Stavanger (Master's Thesis), 2010.

[15]. M.Alam, M.M. Alam., R.J. Curray, R.L.M. Chowdhury \&R.M. Gani, "An Overview of The Sedimentary Geology of The Bengal Basin in Relation to The Regional Framework and BasinFill History, Sedimentary Geology", vol.155, pp.179-208, 2003.

[16]. Z.M.H. Hossain, Y. Sampei, P.B. Roser, "Characterization of Organic Matter and Depositional Environment of Tertiary Mudstones from the Sylhet Basin, Bangladesh" Organic Geochemistry, vol. 40, pp. 743-754, 2009.

[17]. H.F. Khan, Geology of Bangladesh, 1991.

[18]. M.Z. Hossain, P.B. Roser, I.J. Kimura, "Petrography and Whole-Rock Geochemistry of The Tertiary Sylhet Succession, Northeastern Bengal Basin, Bangladesh", Provenance and source area weathering, Sedimentary Geology, vol. 228, pp.171-183, 2010.

[19]. L.S. Melzer, Factors involved in adding carbon capture, utilization and storage (CCUS) to Enhanced Oil Recovery, Melzer consulting, pp. 1-18, 2012.

[20]. Hydrocarbon Unit/Norwegian Petroleum Directorate (HCU/NPD), Bangladesh Petroleum 
INTERNATIONAL JOURNAL OF ENGINEERING TECHNOLOGY AND SCIENCES (IJETS) Vol.5 (1) June 2016 DOI: http://dx.doi.org/10.15282/ijets.5.2016.1.7.1046

Potential and Resource Assessment 2001, Ministry of power, Energy and Mineral Resources, Govt. of the People's Republic of Bangladesh, 2003.

[21]. Petrobangla, National Energy Policy, Government of The People's Republic of Bangladesh, Ministry of Power, Energy and Mineral Resources, 2004. 